\title{
ANALISIS STRATEGI PENGELOLAAN WAKAF PRODUKTIF DI INDONESIA
}

\author{
Dharma Satyawan \\ email : dharmasatyawan@gmail.com \\ Achmad Firdaus \\ Bayu Taufiq Possumah \\ Pasca Sarjana STEI TAZKIA Bogor
}

\begin{abstract}
Islamic Waqif has an important role as one of the instruments in the economic empowerment of the people. In history, awqf played an important role in the development of social, economic and cultural life of the people. Both laws and regulations in the form of Law No. 41 of 2004 and Government Regulation No.42 of 2006 regulating the interests of worship, education, social and more important are the interests of the people's economic welfare.

This study has a general purpose to formulate productive awqf management strategies in Indonesia, with specific objectives as follows: a.Identify constraints in developing productive awqf in Indonesia; b. Formulate productive awqf management strategies in Indonesia as literacy efforts in the field of da'wah in the community.

Research examines the factors that influence the productive awqf management in Indonesia, through interviews of experts and regulators. Then analyze the policy. With the ANP and SWOT methods, that found the Strengths factors are Regulations / Laws and the largest Muslim population in the world. While Weaknesses are a lack of socialization and traditional mindset about awqf. Elements in the SWOT method, which is an opportunity to develop awqf (Opportunity) is the collection of endowments as the main element of worship and Professionalism in managing waqif funds. And the Threats in waqif management are materialistic lifestyle (hedonism) and non-Islamic education patterns. It is expected that the results of this study can provide input to the Regulators (Government and Legislature), Academics, Wakif and the Community beneficiaries of the awqf itself.
\end{abstract}

Key words : SWOT Analysis, ANP method, Waqif, Nazr, BWI

Jurnal Komunikasi Bisnis dan Manajemen

Vol.5 No.2 Juli 2018 


\section{PENDAHULUAN}

Wakaf mempunyai peran penting sebagai salah satu instrumen dalam pemberdayaan ekonomi umat. Dalam sejarah, wakaf memerankan peranan penting dalam pengembangan kehidupan sosial, ekonomi dan budaya masyarakat. Kedua peraturan perundang-undangan berupa Undang-undang No. 41 Tahun 2004 dan Peraturan Pemerintah No.42 Tahun 2006 mengatur kepentingan ibadah "mahdhah"e, pendidikan, sosial dan yang tak kalah pentingnya adalah kepentingan kesejahteraan ekonomi umat.

Disamping itu. potensi wakaf uang di Indonesia yang memiliki jumlah penduduk muslim terbesar di dunia diperkirakan mencapai angka Rp. 3 trilyun dengan perincian berikut (Tabel 1.1):

Tabel 1.1. Perkiraan Penerimaan Wakaf Tunai

\begin{tabular}{|c|c|c|c|c|}
\hline $\begin{array}{l}\text { Tingkat } \\
\text { Penghasilan } \\
\text { /bln }\end{array}$ & $\begin{array}{l}\text { Jumlah } \\
\text { Muslim }\end{array}$ & Wakaf uang/bln & $\begin{array}{l}\text { Jumlah } \\
\text { wakaf uang/bulan }\end{array}$ & $\begin{array}{l}\text { Jumlah Wakaf } \\
\text { uang /tahun }\end{array}$ \\
\hline $\begin{array}{l}\mathrm{s} / \mathrm{d} \\
\mathrm{Rp} .500 .000\end{array}$ & 4 juta & Rp. 5.000 & Rp. $20 \mathrm{M}$ & Rp. $240 \mathrm{M}$ \\
\hline Rp 1 jt -2 jt & 3 juta & Rp. 10.000 & Rp. $30 \mathrm{M}$ & Rp. $360 \mathrm{M}$ \\
\hline Rp. 2 jt -5 jt & 2 juta & Rp. 50.000 & Rp.100 M & Rp. 1,2 T \\
\hline Rp.5-10 jt & 1 juta & Rp. 100.000 & Rp.100 M & Rp. $1.2 \mathrm{~T}$ \\
\hline TOTAL & & & & Rp.3 T \\
\hline
\end{tabular}

Sumber : Mustafa Edwin dalam Rozalinda (2015).

Potensi Wakaf bahkan mencapai sebesar Rp. 11,4 T per tahun yang terdiri dari 145 Lembaga Wakaf (Badan Wakaf Indonesia, 2016).

Pada dasarnya dalam pelaksanaannya, wakaf produktif memiliki dua dimensi yaitu dimensi religi dan dimensi sosial ekonomi. Dimensi religi berarti wakaf yang dilaksanakan merupakan anjuran Allah SWT yang perlu dilakukan oleh setiap muslim yang merupakan bentuk ketaatan seorang muslim kepada Allah. Wakaf bukanlah sedekah, tetapi lebih besar ganjaran dan manfaatnya terutama bagi diri wakif (pelaku wakaf), karena wakaf terus mengalir pahalanya 
selamanya. Dimensi sosial ekonomi adalah karena dalam prakteknya, para pemilik harta wakaf mengulurkan tangannya untuk membantu kesejahteraan manusia.

Wakaf produktif yang dapat diartikan sebagai wakaf yang asetnya, apabila dikelola dapat memberikan keuntungan secara ekonomis yang dapat berupa tanah-tanah perkebunan/pertanian uang dan macam-macam benda bergerak dan tidak bergerak, perlu lebih ditingkatkan manfaatnya dengan membuat mekanisme dan strategi yang lebih terarah.

Wakaf produktif merupakan inovasi dalam keuangan Islam, yang membuka peluang penciptaan investasi di bidang keagamaan, pendidikan serta pelayanan sosial. Disamping itu wakaf produktif (uang) dapat berfungsi sebagai investasi yang strategis untuk menekan angka kemiskinan dan menangani ketertinggalan di bidang ekonomi, pendidikan, kesehatan dan sebagainya.

Tujuan penulisan artikel ini adalah memberikan gambaran kepentingan wakaf produktif bagi perkembangan ekonomi umat, dan memberikan solusi mendakwahkan sosialisasi wakaf produktif ke masyarakat.

\section{METODE PENELITIAN}

Metode yang digunakan dalam penelitian ini adalah metodologi kualitatif dan kuantitatif, Metode kualitatif dilakukan dengan proses diskusi dan studi literatur dalam rangka mendapatkan informasi dari sumber primer dan sekunder. Sedangkan metode kuantitatif dalam penelitian ini menggunakan metode Analytical Network Process (ANP) dan Motode SWOT. Metode ini merupakan metode untuk memahami suatu situasi yang problematik dan mengeksplorasi cara untuk mengelola persoalan tersebut (Ascarya. 2011).

Strategi pengolahan data melalui beberapa tahap yaitu: tahap analisis strategi 
merupakan langkah untuk menentukan alternatif-alternatif strategi yang mungkin dapat diambil dalam pengelolaan wakaf produktif di Indonesia, dilakukan dengan menggunakan analisis SWOT. Analisis ini didasarkan pada logika yang dapat memaksimalkan kekuatan (strengths) dan peluang (opportunities), namun secara bersamaan dapat meminimalkan kelemahan (weakness) dan ancaman (threats) (Rangkuti, 2000). Analisis SWOT dikerjakan dengan mengidentifikasi setiap kekuatan, kelemahan, peluang dan ancaman dalam pengelolaan wakaf produktif di Indonesia. Tahap ini dilakukan dengan membuat matriks SWOT seperti Tabel 3.2.

Tabel 3.2. Matrik SWOT dalam pengelolaan wakaf produktif di Indonesia

\begin{tabular}{|c|c|c|}
\hline \multirow{2}{*}{ Faktor Eksternal } & \multicolumn{2}{|c|}{ Faktor Internal } \\
\cline { 2 - 3 } & $\begin{array}{c}\text { Kekuatan } \\
\text { (Strength) }\end{array}$ & $\begin{array}{c}\text { Kelemahan } \\
\text { (Weakness) }\end{array}$ \\
\hline $\begin{array}{c}\text { Peluang } \\
\text { (Opportunity) }\end{array}$ & Strategi SO & Strategi WO \\
\hline Ancaman (Threat) & Strategi ST & Strategi WT \\
\hline
\end{tabular}

Secara garis besar metode penelitian ini adalah sebagai berikut :

a. Input :

1) Pengelolaan dan strategi perwakafan di Indonesia sesuai dengan regulasi yang berlaku berdasarkan studi literatur dan riset terdahulu

2) Menentukan faktor-faktor yang berperan dalan pengelolaan perwakafan di Indonesia berdasarkan riset-riset terdahulu serta studi literatur

3) Strategi yang diterapkan dalam pengelolaan perwakafan dan penerapan kebijakan pemerintah yang sudah berjalan.

b. Proses

1) Menentukan faktor-faktor yang berpengaruh terhadap strategi pengelolaan wakaf produktif di Indonesia melalui studi literatur, interview dengan para 
pakar dan regulator (Pemerintah).

2) Mengidentifikasi dan merumuskan respon yang diperoleh dari para stake holders wakaf (masyarakat umum).

Tahap berikutnya adalah analisis data dalam penelitian ini menggunakan metode Analytic Network Process (ANP), yai tu metode pendekatan kualitatif dan yang menjadi subyek dalam penelitian ini adalah Regulator Badan Wakaf Indonesia (BWI), serta Akademisi yang memahami masalah Perwakafan.

Analytic Network Process (ANP) adalah teori matematis yang memperbolehkan kita secara sistematis dengan ketergantungan dan umpan balik dan dapat menangkap dan mengkombinasikan faktor-faktor "tangible" dan " intangible" dengan menggunakan skala rasio. ANP sebagai teori pengukuran relative digunakan untuk menurunkan rasio prioritas gabungan dari skala rasio individu yang merefleksikan pengukuran relative antar elemen didalam kriteria kontrol tersebut. ANP adalah pendekatan baru yang menyediakan Kerangka Kerja Umum dalam memperlakukan suatu keputusan tanpa membuat asumsi tentang "independency elemen-elemen pada tingkat yang lebih tinggi dari elemenelemen pada tingkat yang lebih rendah".

Tahapan pengolahan Data dengan Metode ANP dapat dilihat pada Tabel berikut : 


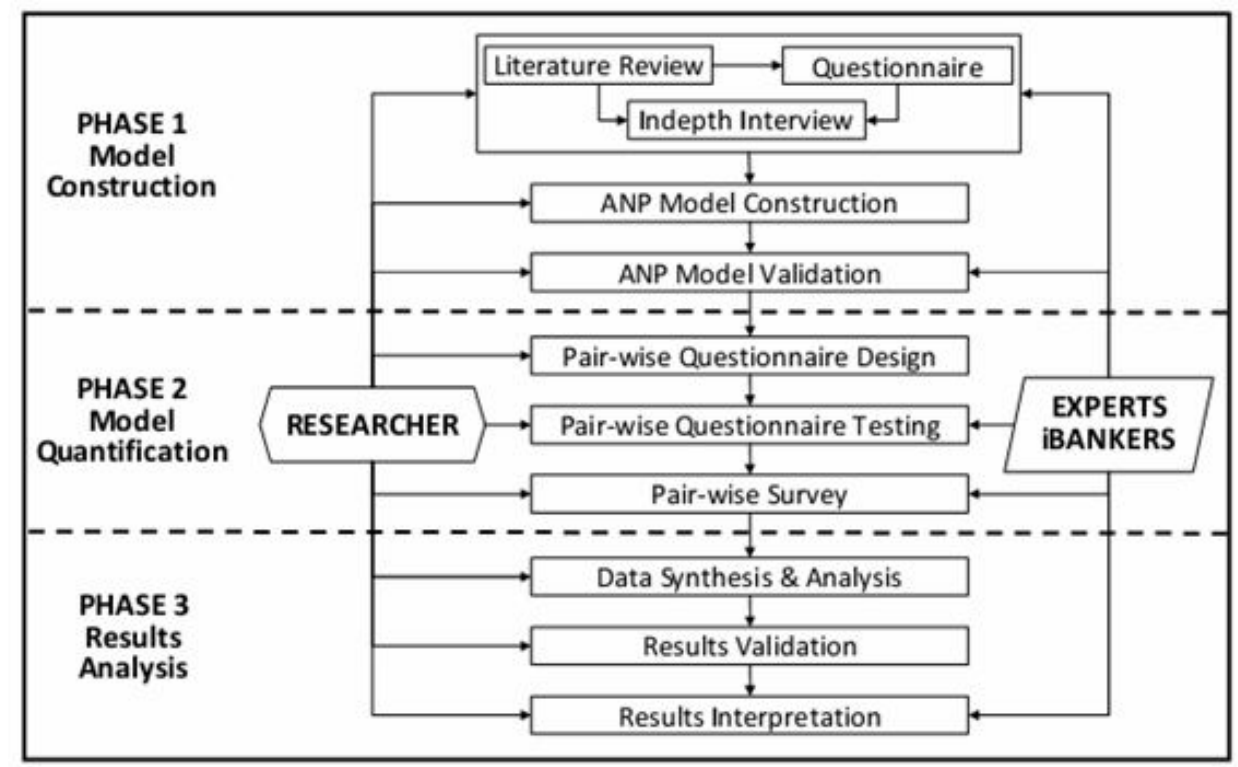

\section{HASIL DAN PEMBAHASAN}

Berdasarkan hasil Indepth-Interview dapat disimpulkan bahwa menurut para pakar dan akademisi serta Regulator sebagai berikut:

\begin{tabular}{|l|l|l|}
\hline $\begin{array}{l}\text { Klasifikasi } \\
\text { (Cluster) }\end{array}$ & Opini (Sub Cluster) \\
\hline Strength & $\begin{array}{l}\text { 1. Regulasi/Perundang-undangan } \\
\text { 2. Jumlah penduduk muslim terbesar di dunia }\end{array}$ \\
\hline Weakness & $\begin{array}{l}\text { 1. Kurangnya Sosialisasi } \\
\text { 2. Pola pikir Tradisional }\end{array}$ \\
\hline Opportunity & $\begin{array}{l}\text { 1. Penghimpunan dana sebagai unsur ibadah } \\
\text { 2. Profesionalisme dalam mengelola dana wakaf }\end{array}$ \\
\hline Thread & $\begin{array}{l}\text { 1. Gaya hidup masyarakat yang materialistis } \\
\text { 2. Pola pendidikan Non Islami }\end{array}$ \\
\hline
\end{tabular}

\begin{tabular}{|l|c|l|c|l|l|}
\hline No & Resp. & $\begin{array}{l}\text { Jabatan/Tempat } \\
\text { Bekerja }\end{array}$ & Pendidikan & $\begin{array}{l}\text { Masa } \\
\text { Bertugas }\end{array}$ & Kategori \\
\hline 1. & A & $\begin{array}{l}\text { Dewan pengawas } \\
\text { BWI }\end{array}$ & S3 & s/d 2017 & Pakar \\
\hline
\end{tabular}




\begin{tabular}{|l|c|l|l|l|l|}
\hline 2. & B & Dirut BNI Syariah & S3 & s/d 2016 & Praktisi/Akademisi \\
\hline 3. & C & Ketua BWI & S3 & s/d 2017 & Regulator \\
\hline 4. & D & $\begin{array}{l}\text { Guru Besar } \\
\begin{array}{l}\text { Fakultas } \\
\text { Hukum UI }\end{array}\end{array}$ & S3 & $\begin{array}{l}\text { s/d } \\
\text { sekarang }\end{array}$ & Akademisi \\
\hline
\end{tabular}

Berdasarkan hasil indepth interview dengan para pakar didapat bahwa : Faktor faktor yang dalam analisis SWOT yang mempengaruhi pengelolaan Perwakafan di Indonesia adalah :

a.. Unsur-unsur Kekuatan (Strength) meliputi :

1). Adanya regulasi/perundangan yang menjadi acuan bagi setiap warga Negara Indonesia dalam pengelolaan wakaf di Indonesia.

Dalam Undang undang Wakaf no. 41 tahun 2004, dinyatakan bahwa lembaga wakaf adalah pranata keagamaan yang memiliki potensi dan manfaat ekonomi yang perlu dikelola secara efisien antara lain untuk kesejahteraan umum. Sehingga langkah strategisnya adalah meningkatkan peran wakaf untuk meningkatkan kesejahteraan umum.

2). Jumlah penduduk Indonesia yang merupakan penduduk muslim terbesar di dunia.

Potensi jumlah penduduk muslim

b. Unsur-unsur yang melemahkan (Weaknesses), meliputi :

1). Kurangnya sosialisasi di masyarakat tentang

pentingnya wakaf 2). Pola pikir tradisional

masyarakat tentang wakaf

c. Unsur-unsur yang menjadi peluang untuk pengelolaan perwakafan adalah :

1). Penghimpunan dana abadi sebagai unsur ibadah utama

dan unsur social Masyarakat.

2). Profesionalisme dalam mengelola dana wakaf.

Jurnal Komunikasi Bisnis dan Manajemen

Vol.5 No.2 Juli 2018 
d. Yang menjadi ancaman dalam pengelolaan wakaf adalah:

1). Gaya hidup dalam masyarakat yang

materialistis (hedonism) 2). Pola pendidikan

yang masih non Islami.

Untuk model ANP dengan metode SWOT adalah sebagai berikut:

\begin{tabular}{|c|c|c|}
\hline No. & Clusters & Sub-Clusters \\
\hline 1. & Opportunities & $\begin{array}{l}\text { 1). Penghimpunan dana abadi sebagai unsur ibadah utama } \\
\text { dan unsur social Masyarakat. } \\
\text { 2). Profesionalisme dalam mengelola dana wakaf. }\end{array}$ \\
\hline 2. & Strengths & $\begin{array}{l}\text { 1). Adanya regulasi/perundangan yang menjadi acuan bagi setiap } \\
\text { warga Negara Indonesia dalam pengelolaan wakaf di Indonesia. } \\
\text { 2). Jumlah penduduk Indonesia yang merupakan penduduk muslim } \\
\text { terbesar di dunia }\end{array}$ \\
\hline \multirow[t]{2}{*}{3.} & Threats & $\begin{array}{l}\text { 1). Gaya hidup dalam masyarakat yang materialistis } \\
\text { (hedonism) }\end{array}$ \\
\hline & & 2). Pola pendidikan yang masih non Islami. \\
\hline 4. & Weaknesses & $\begin{array}{l}\text { 1). Kurangnya sosialisasi di masyarakat tentang } \\
\text { pentingnya wakaf 2). Pola pikir tradisional masyarakat } \\
\text { tentang wakaf }\end{array}$ \\
\hline
\end{tabular}

Berdasarkan hasil pengolahan data didapat bahwa : untuk Kekuatan (Strength) :

1. Regulasi/Perundangan sebagai acuan bagi warganegara

2. Jumlah Penduduk muslim terbesar di dunia

Regulasi/perundang-undangan sangat berperan dalam pengelolaan wakaf ini. Dari latar belakang sejarah perundang-undangan wakaf telah ada sejak zaman sebelum kolonial Belanda. Dalam Undang-undang nomor 41 tahun 2004, dicantumkan bahwa Pengelolaan dan Pengembangan wakaf secara produktif, yang menyiratkan bahwa pengelolaan dan pengembangan wakaf hendaknya memberikan nilai tambah. Kata produktif tidak hanya untuk wakaf uang /tunai 
tetapi juga untuk wakaf dengan set-aset yang tidak bergerak sekalipun (Ishom. 2004)

Jumlah penduduk muslim terbesar (data BPS 2016) : 220 juta jiwa, merupakan kekuatan yang utama dalam usaha pengelolaan wakaf yang produktif. Besarnya umat Islam di Indonesia memberikan potensi Wakaf uang yang sangat besar. Potensi wakaf uang /produktif dihitung sebesar 1,2 trilyun per tahun (Nasution. BWI. 2016).

Sementara dari hasil yang didapat masih sangat kecil, yaitu 1,5 milyar per tahun $2016(0,12 \%)$. Potensi jumlah penduduk muslim terbesar merupakan kekuatan utama untuk pengelolaan wakaf di Indonesia.

\section{Kekuatan}

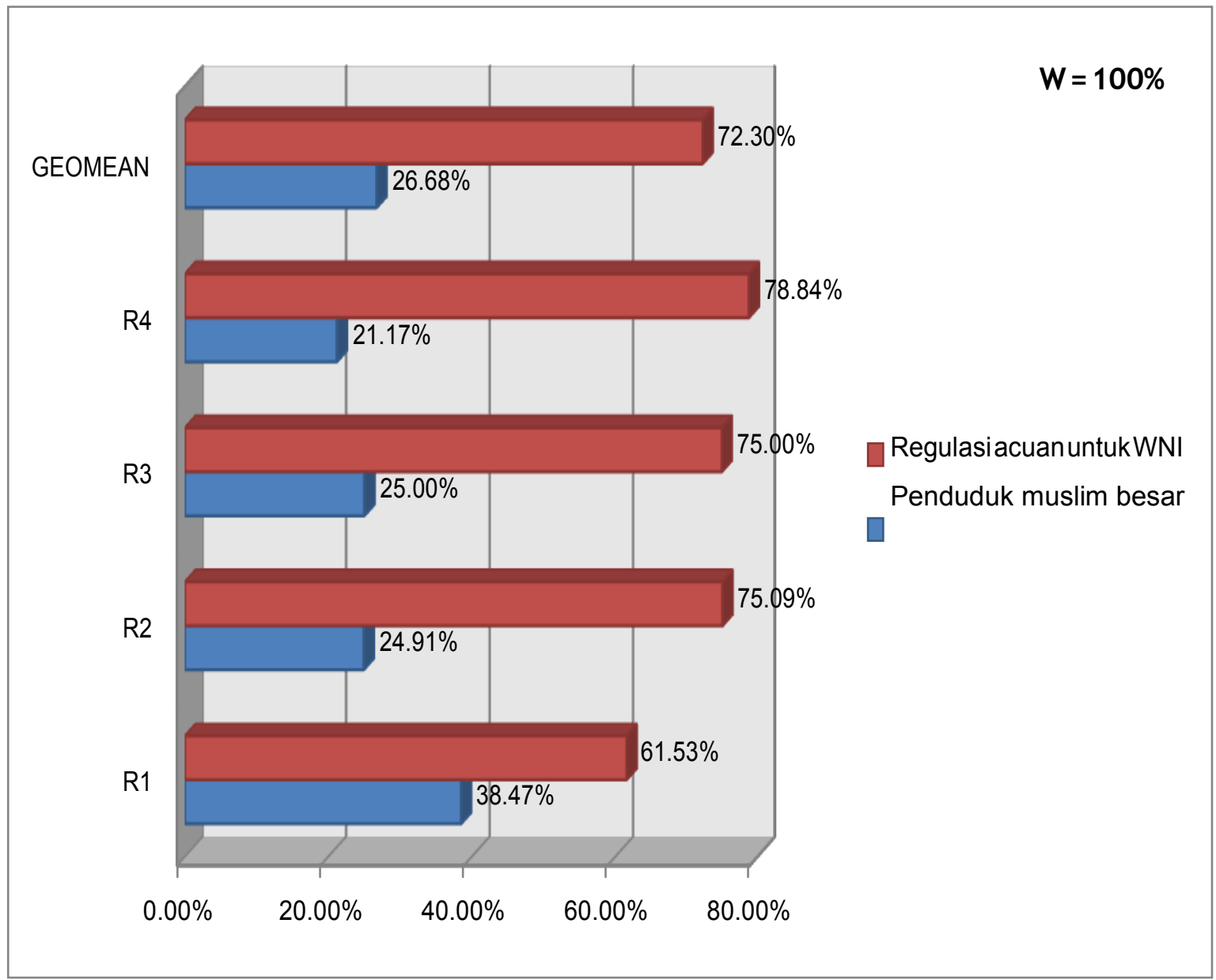

Jurnal Komunikasi Bisnis dan Manajemen

Vol.5 No.2 Juli 2018 
Berdasarkan gambar diatas dapat diartikan bahwa semua responden setuju (W=100\%) bahwa Adanya Regulasi /Perundang-undangan adalah faktor kekuatan yang besar dalam menyusun Strategi Pengelolaan Wakaf Produktif.

Dengan adanya regulasi (Undang-undang) maka semua kebijakan secara nasional akan selalu berpedoman kepada Undang-undang Wakaf Republik Indonesia no.41 tahun 2004.

Undang-undang inipun sudah mempunyai Peraturan Pemerintah no. 42 tahun 2006 yang merupakan Petunjuk Pelaksanaan Undang-undang tersebut. Tingkat persetujuan responden terutama pada faktor Undang-undang ini menunjukkan keberpihakan Negara secara konstitusional. Sedangkan jumlah penduduk muslim terbesar (sekitar 200 juta ) merupakan sumber kekuatan kedua setelah Regulasi/ perundang-undangan, tetapi mempunyai kesenjangan yang cukup signifikan antara kedua faktor tersebut. Secara rata-rata (Geo mean) selisih antara keduanya adalah 46\% , dimana untuk Regulasi, para responden sepakat untuk menempatkannya sebagai faktor utama kekuatan dalam penyusunan Strategi pengelolaan Wakaf Produktif. 


\section{Kelemahan}

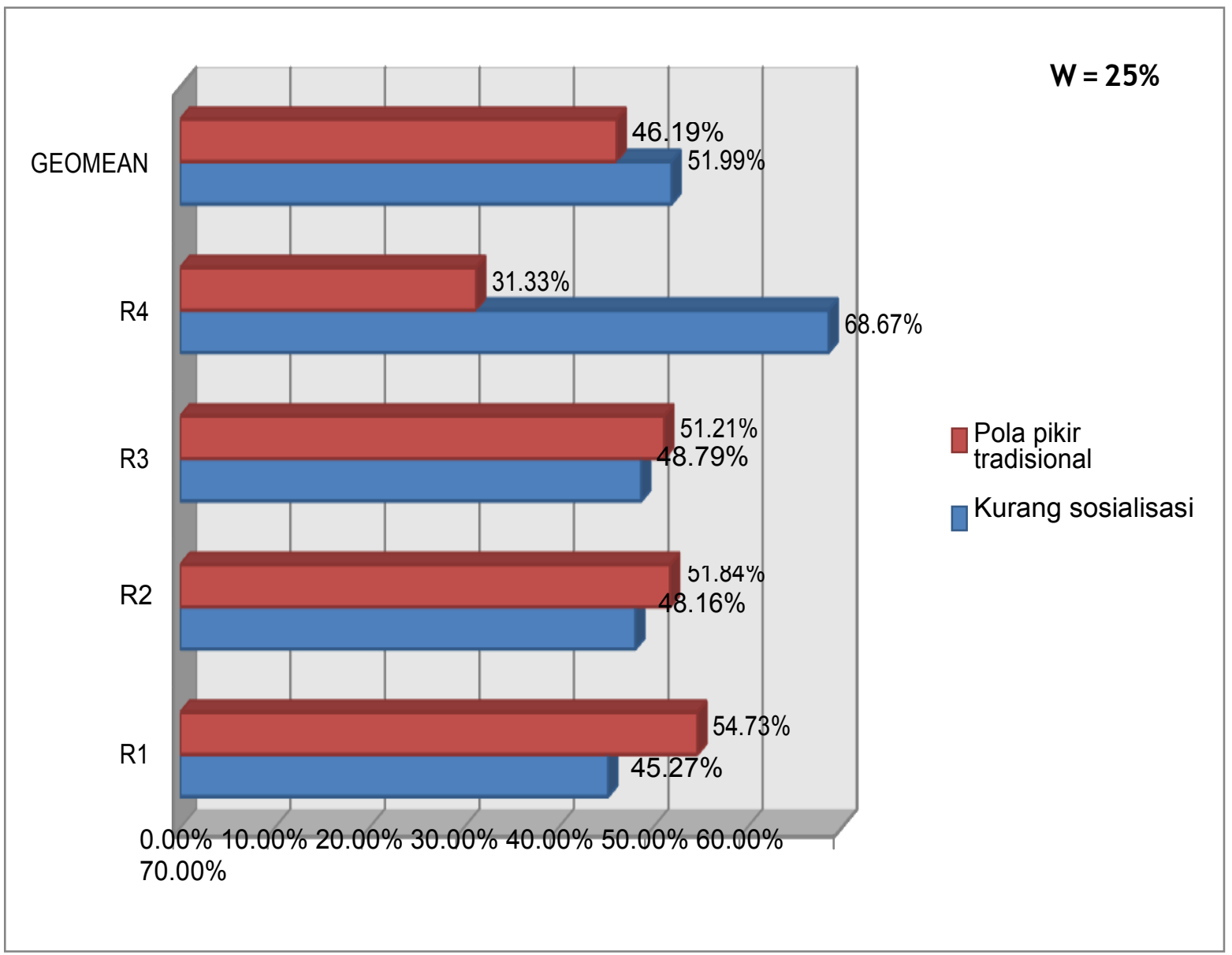

Dengan tingkat persetujuan $25 \%$ para responden berpendapat bahwa faktor Kurangnya sosialisasi adalah faktor yang cukup besar pengaruhnya dalam usaha pengelolaan perwakafan di Indonesia. Memang tidak semua responden berpendapat demikian secara keseluruhan (51,9\%). Pola pikir tradisional juga memegang peranan penting sebagai titik kelemahan pengelolaan wakaf (45,19\%). Tetapi tidak semua responden sependapat, ini dilihat dari nilai W yang dalam skala 0 - 100 hanya pada angka 25 (25\%). 


\section{Peluang}

Faktor peluang (Opportunity), Semua responden sepakat bahwa unsur profesionalisme mengelola wakaf (dalam hal ini Nazir wakaf) sangat berperan dalam memberi kesempatan pengembangan pengelolaan wakaf (59.9\%). Nazir sebagai pengelola harta/asset wakaf yang profesional merupakan kunci keberhasilan dalam upaya strategi manajemen wakaf.

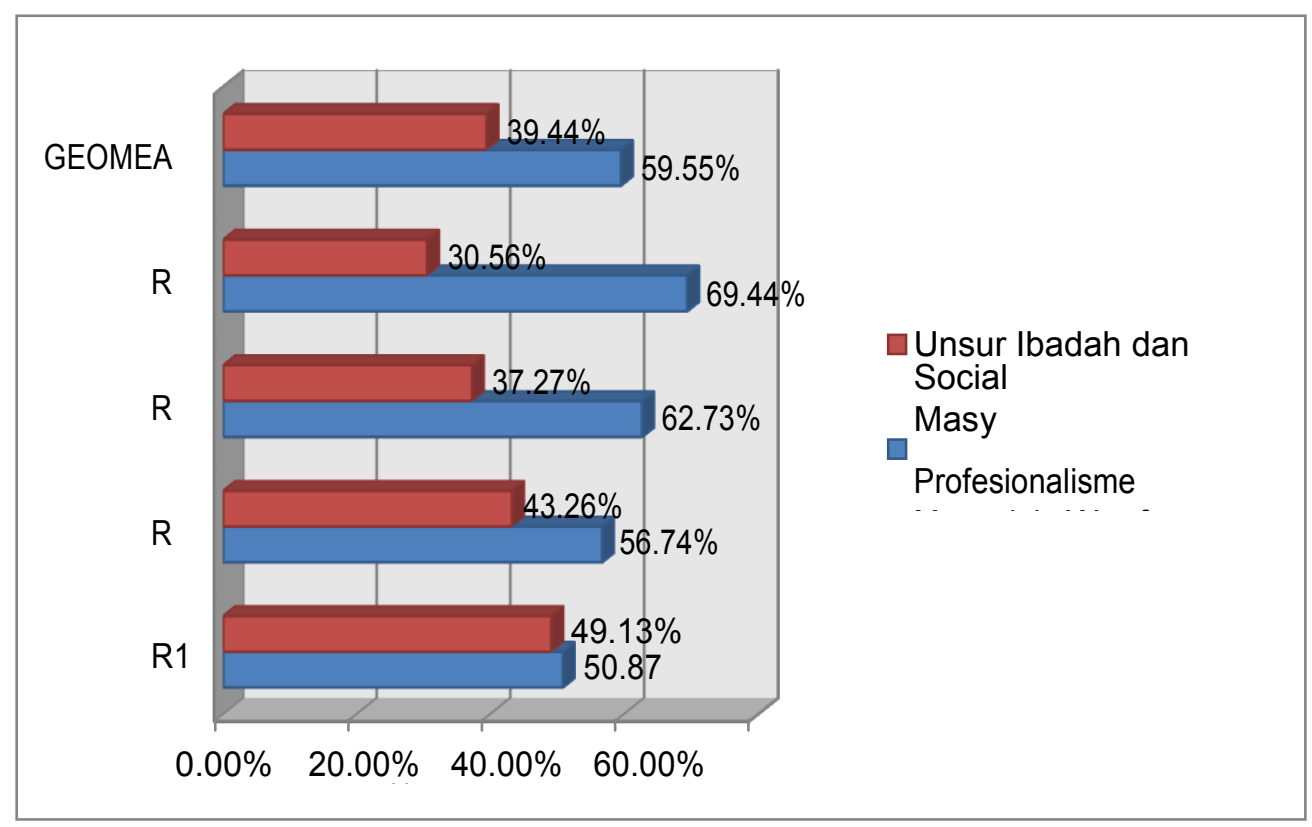

Jurnal Komunikasi Bisnis dan Manajemen

Vol.5 No.2 Juli 2018 


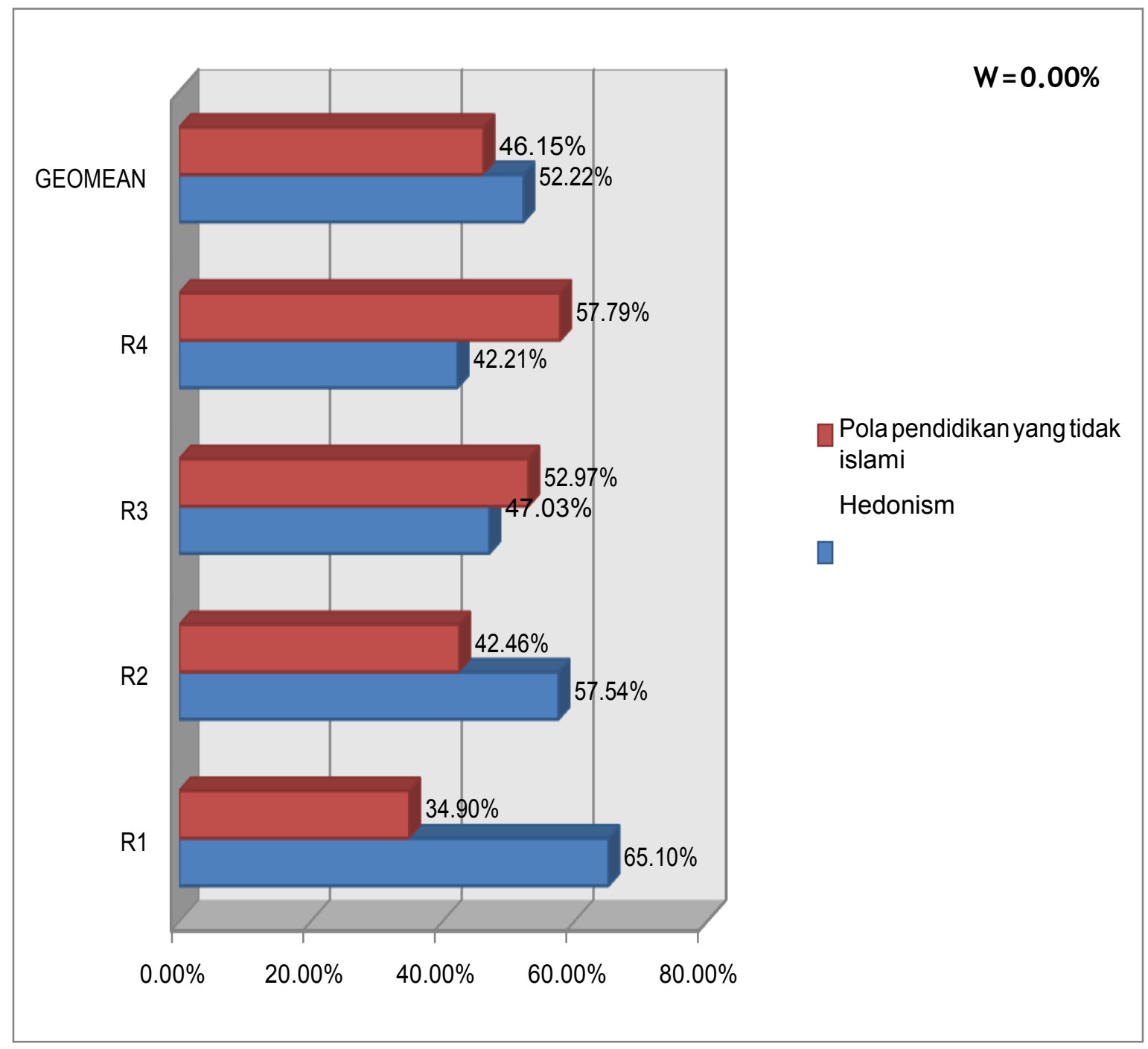

\section{Ancaman}

Untuk faktor Ancaman (Thread), ternyata tidak terdapat kesepakatan diantara responden, sehingga nilai $\mathrm{W}=0$. Baik faktor Pola pendidikan maupun gaya hidup (hedonism) menjadi berpengaruh dalam hal ancaman terhadap pengelolaan wakaf. 


\section{Strategi}

\begin{tabular}{|c|c|c|}
\hline No & & \\
\hline 1. & Strategi 1 & Sosialisasi Wakaf Produktif \\
\hline 2. & Strategi 2 & Peningkatan profesionalisme Nazir \\
\hline 3. & Strategi 3 & Penguatan kelembagaan Badan Wakaf Indonesia (BWI) \\
\hline 4. & $\begin{array}{l}\text { Strategi } 4 \\
\text { Strategi } 5\end{array}$ & $\begin{array}{l}\text { Status hukum harta } \\
\text { wakaf Entrepreneurship } \\
\text { dalam mengelola wakaf. }\end{array}$ \\
\hline
\end{tabular}

Hasil pengolahan dengan menggunakan metode ANP adalah sebagai berikut:

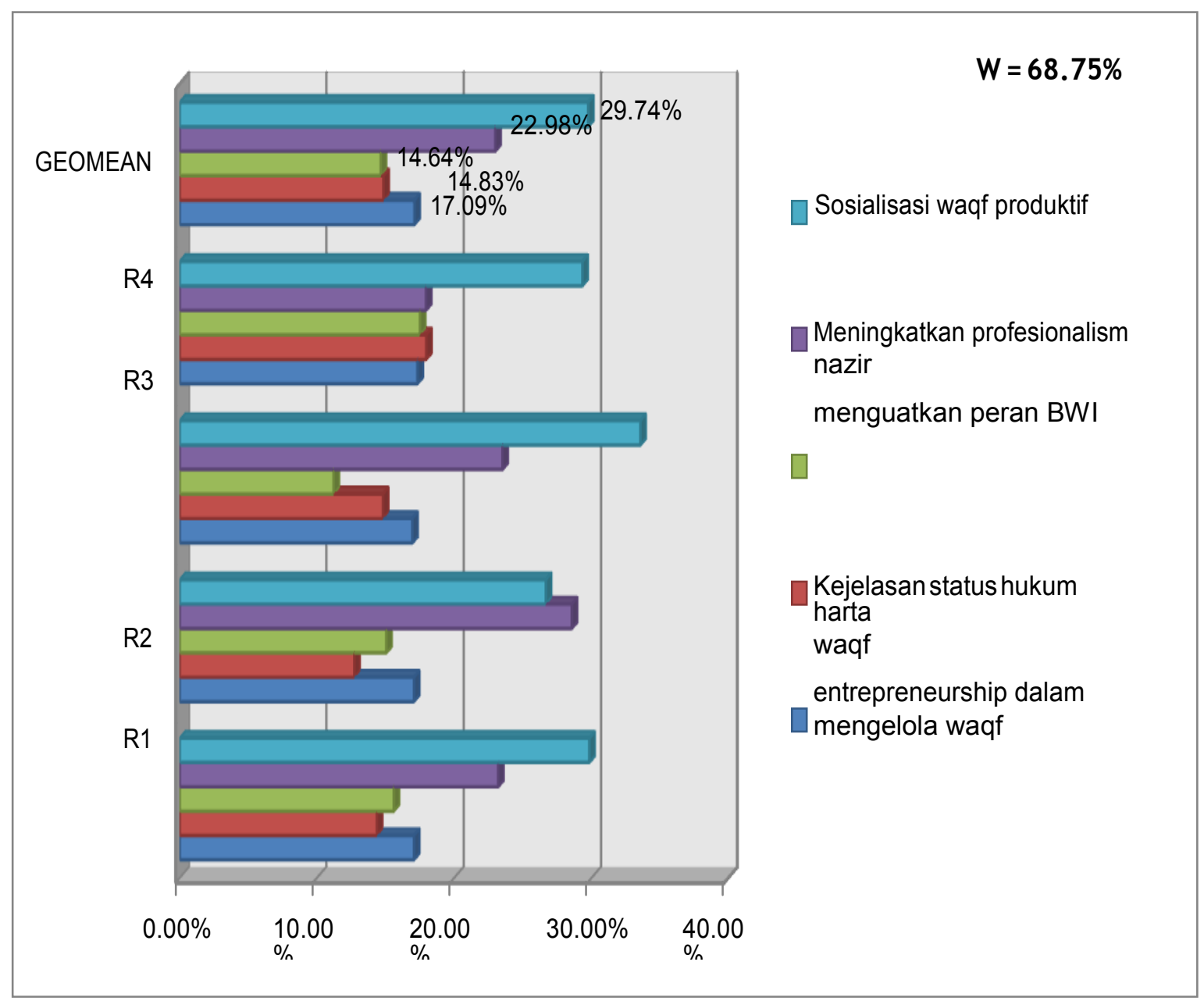

Jurnal Komunikasi Bisnis dan Manajemen

Vol.5 No.2 Juli 2018 
Dalam penyusunan Strategi pengelolaan wakaf, semua responden sepakat $(68.7 \%)$ bahwa sosialisasi wakaf produktif menjadi faktor utama penentu keberhasilan pengelolaan wakaf. $(29,7 \%)$ Upaya meningkatkan profesionalisme para Nazir menjadi prioritas kedua setelah sosialisasi $(22,9 \%)$

Dalam Model ANP digambarkan sebagai berikut :

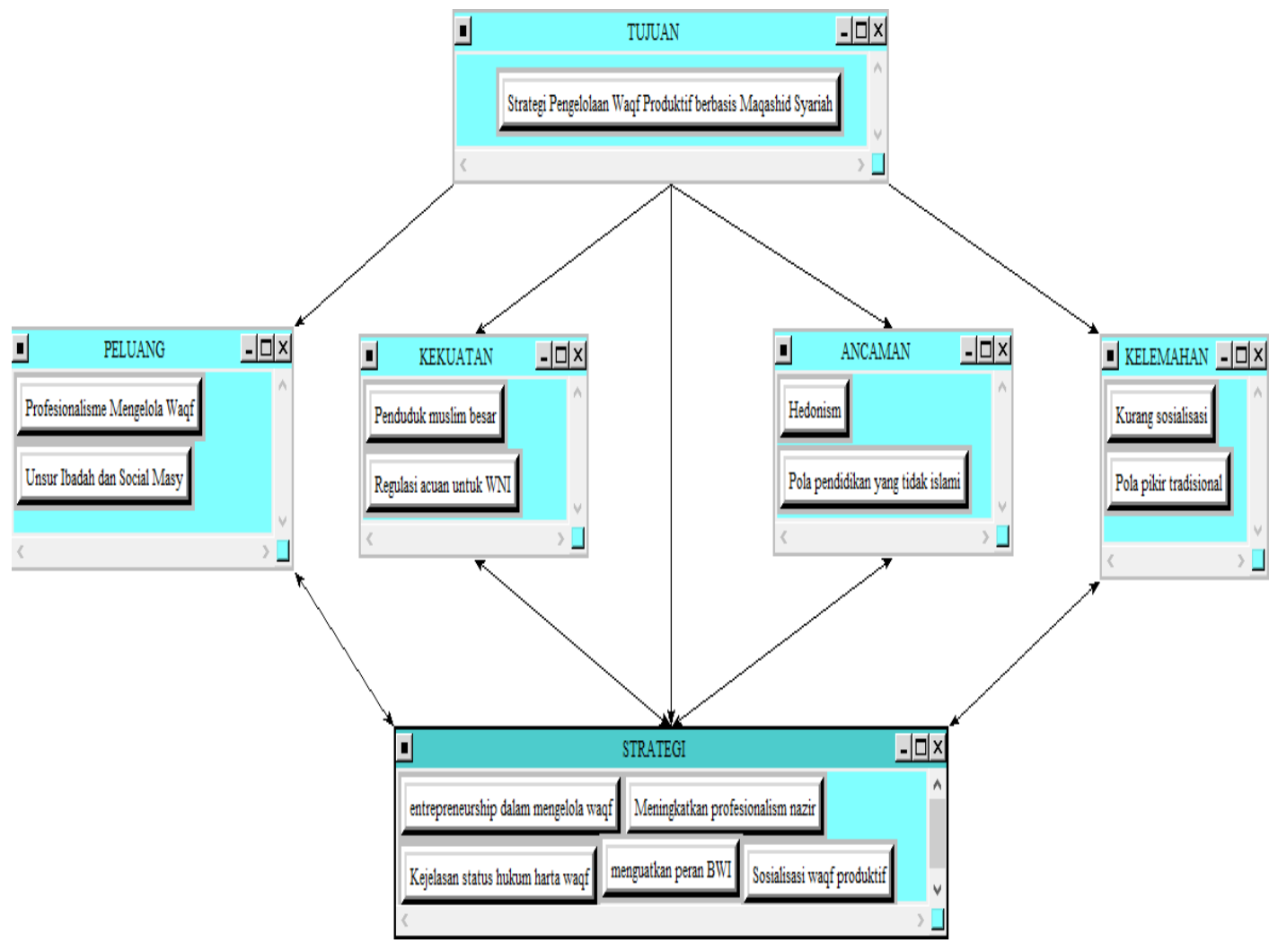

\section{KESIMPULAN}

1. Regulasi/Perundang-undangan merupakan suatu potensi kekuatan untuk pengelolaan wakaf produktif

2. Para responden sepakat bahwa Kurangnya Sosialisasi menjadi salah satu 
kelemahan dalam Strategi Pengelolaan Wakaf Produktif di Indonesia

3.. Proses Sosialisasi merupakan Strategi utama (yang diprioritaskan) dalam upaya memasyarakatkan wakaf produktif di Indonesia.

4. Peningkatan profesionalisme Nazir yang menjadi peluang untuk pengembangan wakaf produktif.

\section{DAFTAR PUSTAKA}

Ascarya, 2011,"The Persistence of Low Profit and Loss Sharing Financing in Islamic Banking: The Case of Indonesia" review of Indonesian economic and business studies vol.1 LIPI economic research center.

Mu"allim M. et. Abdurrahman. 2014. Jurnal Bimas Islam. Vol. VII, Nomor:IV. IAIN Ambon. Ambon.

Qahaf, M. 2005. Manajemen Wakaf Produktif Terjemah oleh H Muhyidin Mas Ridha. Khalifa. Jakarta

Rosalinda. 2015. Manajemen Wakaf Produktif. PT Raja Grafindo Persada, Depok

Tanjung, H. Devi, A. 2013. Metodologi Penelitian Islam. Gramata Publishing. Jakarta

Undang-undang no. 41 tahun 2004 tentang Wakaf.

Jurnal Komunikasi Bisnis dan Manajemen

Vol.5 No.2 Juli 2018 